\title{
Role of Anterior Intralaminar Nuclei of Thalamus Projections to Dorsomedial Striatum in Incubation of Methamphetamine Craving
}

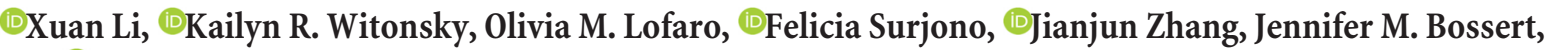 \\ and $\mathbb{P}$ Yavin Shaham \\ Behavioral Neuroscience Research Branch, Intramural Research Program, National Institute on Drug Abuse, National Institutes of Health, Baltimore, \\ Maryland 21224
}

Relapse to methamphetamine (Meth) seeking progressively increases after withdrawal from drug self-administration (incubation of Meth craving). We previously demonstrated a role of dorsomedial striatum (DMS) dopamine D1 receptors (D1Rs) in this incubation. Here, we studied the role of afferent glutamatergic projections into the DMS and local D1R-glutamate interaction in this incubation in male rats. We first measured projection-specific activation on day 30 relapse test by using cholera toxin $b$ (retrograde tracer) + Fos (activity marker) double-labeling in projection areas. Next, we determined the effect of pharmacological reversible inactivation of lateral or medial anterior intralaminar nuclei of thalamus (AIT-L or AIT-M) on incubated Meth seeking on withdrawal day 30 . We then used an anatomical asymmetrical disconnection procedure to determine whether an interaction between AIT-L $\rightarrow$ DMS glutamatergic projections and postsynaptic DMS D1Rs contributes to incubated Meth seeking. We also determined the effect of unilateral inactivation of AIT-L and D1R blockade of DMS on incubated Meth seeking, and the effect of contralateral disconnection of AIT-L $\rightarrow$ DMS projections on nonincubated Meth seeking on withdrawal day 1 . Incubated Meth seeking was associated with selective activation of AIT $\rightarrow$ DMS projections; other glutamatergic projections to DMS were not activated. AIT-L (but not AIT-M) inactivation or anatomical disconnection of AIT-L $\rightarrow$ DMS projections decreased incubated Meth seeking. Unilateral inactivation of AIT-L or D1R blockade of the DMS had no effect on incubated Meth craving, and contralateral disconnection of AIT-L $\rightarrow$ DMS projections had no effect on nonincubated Meth seeking. Our results identify a novel role of AIT-L and AIT-L $\rightarrow$ DMS glutamatergic projections in incubation of drug craving and drug seeking.

Key words: anterior intralaminar nuclei of thalamus; dorsomedial striatum; glutamate; methamphetamine; relapse; retrograde tracing

Significance Statement

Methamphetamine seeking progressively increases after withdrawal from drug self-administration, a phenomenon termed incubation of methamphetamine craving. We previously found that D1R-mediated dopamine transmission in the dorsomedial striatum plays a critical role in this incubation phenomenon. Here, we used neuroanatomical and neuropharmacological methods in rats to demonstrate that an interaction between the glutamatergic projection from the lateral anterior intralaminar nuclei of the thalamus to the dorsomedial striatum and local dopamine D1 receptors plays a critical role in relapse to methamphetamine seeking after prolonged withdrawal. Our study identified a novel motivation-related thalamostriatal projection critical to relapse to drug seeking.

\section{Introduction}

High relapse rates during abstinence is a key feature of methamphetamine (Meth) addiction (Elkashef et al., 2008). In rats given

Received Oct. 4, 2017; revised Jan. 10, 2018; accepted Jan. 15, 2018.

Author contributions:X.L., J.M.B., and Y.S. designed research;X.L., K.R.W., O.M.L., F.S., J.Z., and J.M.B. performed research; X.L., K.R.W., O.M.L., F.S., and Y.S. analyzed data; X.L. and Y.S. wrote the paper.

This work was supported by intramural funds of National Institute on Drug Abuse, National Institutes of Health (Y.S.). J.Z. received support from the China Scholarship Council (No. 201604910135). We thank Tamara Zeric and Angelica Minier-Toribio for technical support. We also thank the National Institute on Drug Abuse Intramural Genetic Engineering and Viral Vector Core for providing the scAAV2-retro-eGFP virus. extended access to intravenous Meth self-administration, drug seeking progressively increases after withdrawal (Shepard et al.,

\footnotetext{
The authors declare no competing financial interests.

Correspondence should be addressed to either X. (Anna) Li or Y. Shaham at the above address. E-mail: annali@umd.edu or yavin.shaham@nih.gov.

X. Li's present address: Department of Psychology, University of Maryland College Park, College Park, MD, 20742, USA. J. Zhang's present address: Chinese Academy of Sciences Key Laboratory of Mental Health, Institute of Psychology, Beijing 100101, China.

DOI:10.1523/JNEUROSCI.2873-17.2018

Copyright $\odot 2018$ the authors $\quad 0270-6474 / 18 / 382270-13 \$ 15.00 / 0$
} 
2004; Adhikary et al., 2017). This incubation phenomenon, which is also observed with other abused drugs (Pickens et al., 2011), generalizes to Meth users who show increased cueinduced drug craving during the first 3 months of abstinence (Wang et al., 2013). In mechanistic studies, we showed that the central amygdala nucleus is critical for incubation of Meth craving (Li et al., 2015a). Scheyer et al. (2016) showed that with Meth, as with cocaine (Wolf, 2016), the accumulation of calciumpermeable AMPARs in the nucleus accumbens is critical for this incubation.

We also explored the role of the dorsomedial striatum (DMS) and the dorsolateral striatum (DLS), previously implicated in relapse to drug seeking and cue-controlled drug seeking in different rodent models (Vanderschuren et al., 2005; Fuchs et al., 2006; Belin and Everitt, 2008; Rubio et al., 2015), in incubation of Meth craving. We found that this incubation is associated with activation [assessed by the activity marker Fos (Cruz et al., 2013)] of both the DMS and the DLS and that local injections of the D1family receptor (D1R) antagonist SCH23390, which inhibits striatal Fos induction (Valjent et al., 2000), decreases "incubated" Meth seeking after 30 withdrawal days (Li et al., 2015b). We also studied the role of the DMS in incubation of Meth craving after choice-based "voluntary abstinence" (Caprioli et al., 2015; Venniro et al., 2017). We used the Daun02 chemogenetic inactivation procedure (Cruz et al., 2013) and demonstrated a role of DMS neuronal ensembles (identified by Fos) in incubated Meth seeking after 21 voluntary abstinence days (Caprioli et al., 2017). These studies demonstrate critical roles of D1R-mediated dopamine transmission in the DLS and the DMS, and of DMS neuronal ensembles, in incubation of Meth craving.

Based on the above results, and evidence that striatal neuronal activity is dependent on activation of glutamate afferents and local D1R-mediated neurotransmission (O'Donnell, 2003; Lovinger, 2010; Shiflett and Balleine, 2011), our goal in the present study was to identify afferent projections to the DMS that interact with local postsynaptic D1Rs and mediate incubated Meth seeking after prolonged withdrawal $(30 \mathrm{~d})$. We first used the retrograde tracer cholera toxin b (CTb) in combination with Fos (Marchant et al., 2009, 2014) to determine whether incubated Meth seeking is associated with activation of glutamatergic projections into the DMS. These include the ventral and dorsal medial prefrontal cortex (vmPFC and dmPFC), the anterior insular (AI) cortex, the basolateral amygdala (BLA), the lateral anterior intralaminar nuclei of thalamus (AIT-L; central lateral and paracentral thalamus), the medial AIT (AIT-M; central medial thalamus), and the parafascicular thalamus (Pf; Voorn et al., 2004; Guo et al., 2015; Hunnicutt et al., 2016).

We found that incubated Meth seeking was associated with selective activation of AIT-L and of AIT $\rightarrow$ DMS projections. Next, we determined the causal role of the AIT nuclei in incubated Meth seeking by using a muscimol+baclofen reversible inactivation procedure (McFarland and Kalivas, 2001). We found that inactivation of AIT-L but not AIT-M decreased incubated Meth seeking. Next, we tested the hypothesis that synergetic activation of AIT-L $\rightarrow$ DMS glutamatergic projections (Fremeau et al., 2001, 2004) and local D1Rs in the DMS control incubated Meth seeking. We used a variation of a reversible asymmetric pharmacological inactivation procedure in which the glutamatergic cell bodies (e.g., AIT-L) are unilaterally inhibited by muscimol+baclofen and postsynaptic dopamine receptors in the target projection area are blocked in either the ipsilateral or contralateral hemisphere by a dopamine receptor antagonist (Bossert et al., 2012; Jenni et al., 2017). Because both ipsilateral and contralateral inactivation of AIT-L $\rightarrow$ DMS projections decreased incubated Meth craving, we also tested the effect of unilateral inactivation of AIT-L and unilateral D1R blockade in the DMS on incubated Meth seeking. Finally, to determine whether the role of AIT-L $\rightarrow$ DMS projections in Meth seeking is specific to incubated Meth seeking, we tested the effect of contralateral disconnection of AIT-L $\rightarrow$ DMS projections on nonincubated Meth seeking on withdrawal day 1 .

\section{Materials and Methods}

Subjects

We used male Sprague Dawley rats (Charles River; total $n=284$ ), weighing 300-350 g before surgery and 325-375 g at the start of the drug self-administration procedure; we maintained the rats under a reverse 12:12 h light/dark cycle (lights on at 8:00 P.M., off at 8:00 A.M.) with food and water available ad libitum. We housed two rats per cage before surgery and then individually after surgery. We performed the experiments in accordance with the National Institutes of Health Guide for the Care and Use of Laboratory Animals (eighth edition) under the protocols approved by the Animal Care and Use Committee. We excluded some rats because of failure of catheter patency (Exp. 3, $n=1$ ), cannula blockage (Exp. 3, $n=1$ ), incorrect cannula placements (pilot food study, $n=1$; Exp. 2, $n=24$; Exp. 3, $n=32$; disconnection food study, $n=4$; Exp. 4, $n=11$; Exp. 5, $n=10$ ), incorrect CTb injections (Exp. 1, $n=11$ ), failure to acquire reliable Meth self-administration (Exp. 2, $n=10$; Exp. 3, $n=$ 2; Exp. 4, $n=3$; Exp. 5, $n=1$ ), or health-related issues (Exp. 1, $n=1$; pilot food study, $n=1$; Exp. 2, $n=4$; Exp. 3, $n=12$; Exp. 4, $n=8$; Exp. 5: $n=2)$.

\section{Intravenous surgery}

We anesthetized the rats with isoflurane gas (5\% induction; $2-3 \%$ maintenance) and inserted Silastic catheters into each rat's jugular vein, as previously described (Lu et al., 2007; Bossert et al., 2009; Theberge et al., 2013). We injected the rats with ketoprofen $(2.5 \mathrm{mg} / \mathrm{kg}$, s.c.) after surgery to relieve pain and inflammation and allowed the rats to recover for 5 $7 \mathrm{~d}$ before Meth self-administration training. During the recovery and training phases, we flushed the catheters every $24-48 \mathrm{~h}$ with gentamicin (APP Pharmaceuticals; $4.25 \mathrm{mg} / \mathrm{ml}$ ) dissolved in sterile saline.

\section{CTb injection into the DMS}

On withdrawal day 15, we injected CTb (List Biological Laboratories) into the DMS. We injected $80 \mathrm{nl}$ of $1 \%$ CTb unilaterally into the DMS over $4 \mathrm{~min}$ with the needle left in place for an additional $2 \mathrm{~min}$ (Marchant et al., 2009, 2014, 2016). We counterbalanced our injections into either the left or right hemisphere and used a $1.0 \mu \mathrm{l}, 32$ gauge Neuros syringe (Hamilton) attached to UltraMicroPump (UMP3) with SYS-Micro4 Controller (World Precision Instruments). The coordinates for the DMS were as follows: anteroposterior (AP), $+1.2 \mathrm{~mm}$; mediolateral (ML), $\pm 2.4 \mathrm{~mm}$ ( $8^{\circ}$ angle); dorsoventral (DV), $-5.3 \mathrm{~mm}$. These coordinates are based on our previous studies (Bossert et al., 2009; Li et al., 2015b).

\section{Intracranial surgery}

We implanted guide cannulas (23 gauge; Plastics One) $1.7 \mathrm{~mm}$ above the AIT-L and AIT-M, and $1.0 \mathrm{~mm}$ above the DMS. We set the nose bar at $-3.3 \mathrm{~mm}$ and used the following coordinates from bregma: AIT-L: AP, $-2.7 \mathrm{~mm}$; ML, $\pm 1.8 \mathrm{~mm}$ ( $8^{\circ}$ angle); DV , $-5.3 \mathrm{~mm}$; AIT-M: AP, $-2.7 \mathrm{~mm}$, $\mathrm{ML}, \pm 2.4 \mathrm{~mm}\left(30^{\circ}\right.$ angle); DV, $-6.2 \mathrm{~mm}$; and DMS: AP, $+1.2 \mathrm{~mm}$; $\mathrm{ML}, \pm 2.4 \mathrm{~mm}\left(8^{\circ}\right.$ angle); DV,$-4.3 \mathrm{~mm}$. We implanted bilateral cannulas into the AIT-L and DMS, and a single cannula into the AIT-M because of its medial location. We anchored the cannulas to the skull with jeweler's screws and dental cement. We used the above coordinates based on previous studies (Porter et al., 2001; Newman and Mair, 2007; Mair and Hembrook, 2008; Bossert et al., 2009; Li et al., 2015b).

\section{Intracranial injections}

We dissolved muscimol+baclofen (Tocris Bioscience) or SCH23390 (Tocris Bioscience) in sterile saline and injected the drugs $15 \mathrm{~min}$ before starting the relapse test sessions. The doses of muscimol+baclofen $(3+$ $15 \mathrm{ng}$ in $0.3 \mu \mathrm{l} /$ side) are based on an initial food self-administration study 
(see below). The dose of SCH23390 ( $0.75 \mu \mathrm{g}$ in $0.5 \mu \mathrm{l} / \mathrm{side})$ is based on our previous studies (Bossert et al., 2009; Li et al., 2015b). The injectors extended 1.7 or $1.0 \mathrm{~mm}$ below the tips of the guide cannulas for the AIT and DMS, respectively. We injected vehicle (saline) or drug at a rate of $0.5 \mu \mathrm{l} / \mathrm{min}$ and left the injectors in place for an additional minute to allow diffusion. We connected the syringe pump (Harvard Apparatus) to $10 \mu \mathrm{l}$ Hamilton syringes and attached the Hamilton syringes to the 30 gauge injectors via polyethylene-50 tubing. After testing, we extracted the rats' brains and stored them in 10\% formalin. We sectioned the rat brains (50 $\mu \mathrm{m}$ sections) using a Leica cryostat and stained the sections with cresyl violet. Finally, we verified cannula placements under a light microscope.

\section{Apparatus}

We trained the rats in self-administration chambers located inside sound-attenuating cabinets and controlled by a Med Associates system. Each chamber had two levers located $8-9 \mathrm{~cm}$ above the floor. During self-administration training, presses on the retractable (active) lever activated the infusion pump (which delivered a Meth infusion; see specific experiments); presses on the stationary (inactive) lever were not reinforced. For intravenous infusions, we connected each rat's catheter to a liquid swivel (Instech) via polyethylene-50 tubing, protected by a metal spring. We then attached the liquid swivel to a $20 \mathrm{ml}$ syringe via polyethylene-50 tubing and to a 22 gauge modified cannula (Plastics One).

\section{Food self-administration training}

We trained the rats to self-administer food pellets (TestDiet, catalog \#1811155) for $1 \mathrm{~h}$ per day during either the beginning (Exp. 2) or the middle (Exp. 3) of their dark cycle, under a fixed ratio 1 (FR-1) $20 \mathrm{~s}$ timeout reinforcement schedule; pellet delivery was paired with a $5 \mathrm{slight}$ cue. To increase rats' motivation to press for the food pellets, we restricted their diet in the home cage to $20 \mathrm{~g} / \mathrm{d}$ and fed them after they finished the food self-administration session. Additionally, to facilitate acquisition of food self-administration, we gave $1 \mathrm{~h}$ magazine training before the operant training during the first 2 training days. During magazine training, we presented the food pellets to the rats every $5 \mathrm{~min}$; pellet delivery was paired with the $5 \mathrm{~s}$ light cue.

\section{Meth self-administration training}

We used an extended access training procedure based on our previous studies (Li et al., 2015a,b). We trained the rats to self-administer Meth for $6 \mathrm{~h}$ per day (two $3 \mathrm{~h}$ sessions separated by $30 \mathrm{~min}$ or one $6 \mathrm{~h}$ session) under a FR-1 20 s timeout reinforcement schedule. We dissolved Meth in saline, and the rats self-administered Meth at a dose of $0.1 \mathrm{mg} / \mathrm{kg} / \mathrm{infu}-$ sion over $3.5 \mathrm{~s}$ ( $0.1 \mathrm{ml} /$ infusion $)$. We trained the rats for 10 sessions over an $11 \mathrm{~d}$ period (one off-day after the fourth or fifth training day) to prevent loss of body weight during the training phase. [Note: Methtrained rats lost $\sim 10-15 \mathrm{~g}$ after 4 or $5 \mathrm{~d}$ of training and regained the lost weight during the off day (data not shown)].

The daily training sessions started at the onset of the dark cycle. The sessions began with the extension of the active lever and the illumination of the red house light, which remained on for the duration of each session. During training, active lever presses led to the delivery of a Meth infusion and a compound $5 \mathrm{~s}$ tone-light cue [the tone and light modules (Med Associates) were located above the active lever]. During the $20 \mathrm{~s}$ timeout, we recorded nonreinforced active lever presses. To prevent overdose, we set the maximal number of daily drug intake to $<90$ infusions. The red house light was turned off and the active lever retracted after the rats received the maximal infusions or at the end of each session. The training data from Experiments 1-5 are described in Figure 1.

\section{Withdrawal phase}

During this phase, we housed the rats individually in the animal facility and handled them 3-4 times per week.

\section{Relapse tests}

We conducted all relapse tests immediately after the onset of the dark cycle. The sessions began with the extension of the active lever and the illumination of the red house light, which remained on for the duration of the session. Active lever presses during testing [the operational mea-
A Exp. 1. CTb injection into DMS
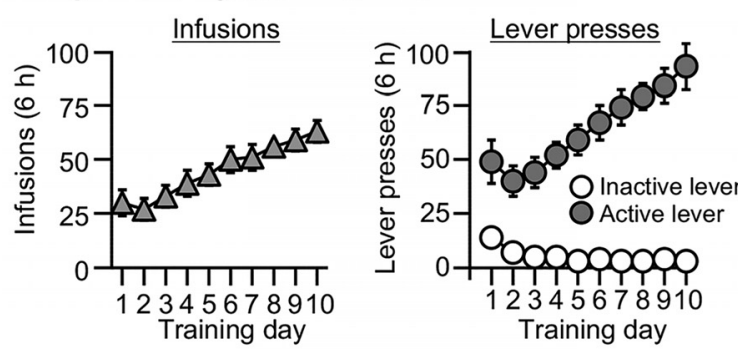

B Exp. 2. Reversible inactivation of AIT-L and AIT-M
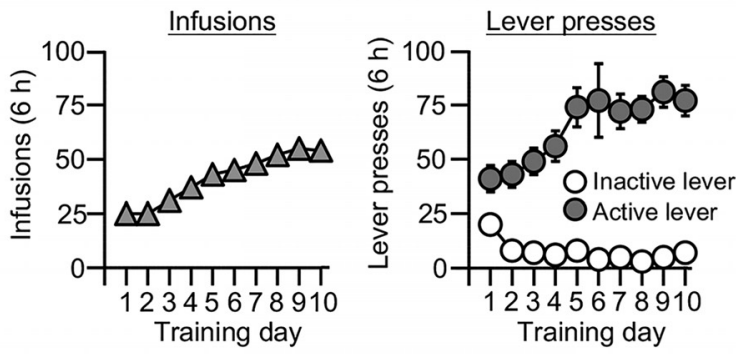

C Exp. 3. AIT-L $\rightarrow$ DMS disconnection
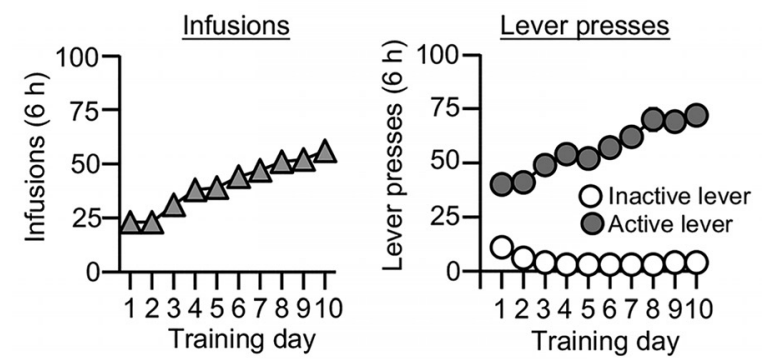

D Exp. 4. Unilateral inactivation of DMS and AIT-L
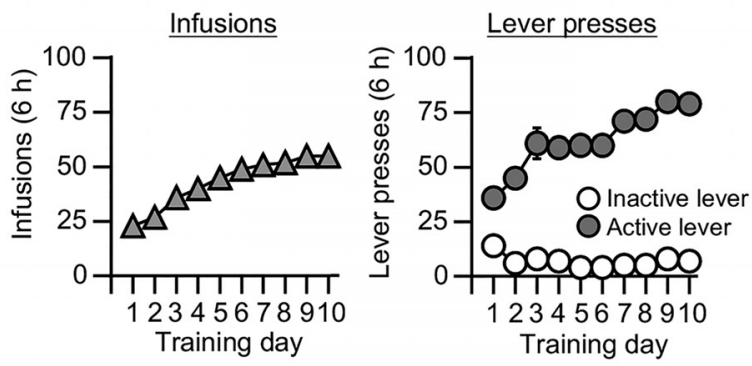

E Exp. 5. AlT-L $\rightarrow$ DMS disconnection (Day 1 withdrawal)
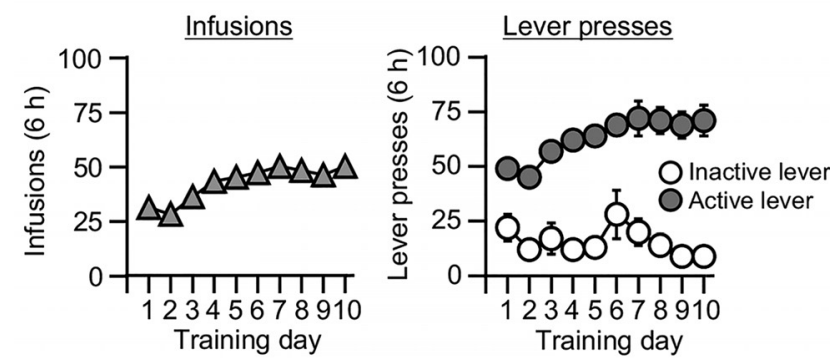

Figure 1. Meth self-administration training. Data are mean \pm SEM number of Meth $(0.1 \mathrm{mg} / \mathrm{kg} /$ infusion) infusions or lever presses during the $106 \mathrm{~h}$ daily self-administration sessions for Experiments 1-5 (total $n=10$ for Exp. 1; 32 for Exp. 2; 39 for Exp. 3; 34 for Exp. 4; 17 for Exp. 5). During training, active lever presses were reinforced on an FR-1 $20 \mathrm{~s}$ timeout reinforcement schedule, and Meth infusions were paired with a 5 s tone-light cue. 
sure of drug seeking in incubation of craving and relapse/reinstatement studies (Shalev et al., 2002; Lu et al., 2004; Pickens et al., 2011)] resulted in contingent presentations of the tone-light cue, previously paired with Meth infusions, but not the drug itself (i.e., under extinction conditions).

\section{Immunohistochemistry}

Immediately after the relapse tests on withdrawal day 30 , we anesthetized the rats with isoflurane and perfused them transcardially with $\sim 100 \mathrm{ml}$ of $0.1 \mathrm{~m}$ PBS followed by $400 \mathrm{ml}$ of $4 \%$ paraformaldehyde (PFA) in PBS. We extracted the brains and postfixed them in $4 \%$ PFA for $2 \mathrm{~h}$, then transferred them to $30 \%$ sucrose in PBS for $48 \mathrm{~h}$ at $4^{\circ} \mathrm{C}$. We froze the brains on dry ice before sectioning. We cut serial coronal sections $(40 \mu \mathrm{m})$ using a Leica Microsystems cryostat and preserved the sections in cryoprotectant (20\% glycerol and 2\% DMSO in PBS, pH 7.4).

\section{$\mathrm{CTb}+$ Fos double-labeling}

We processed a one-in-five series of sections from the PFC ( $\mathrm{dmPFC}$ and vmPFC), AI cortex, DMS, BLA, AIT-L, AIT-M, and Pf from each rat for immunochemical detection of $\mathrm{CTb}$ and Fos. We repeatedly rinsed freefloating sections in PBS $(3 \times 10$ min washes $)$ and incubated them for $1 \mathrm{~h}$ in $10 \%$ normal horse serum (NHS) in PBS with $0.5 \%$ Triton X-100 (PBS-Tx). We then incubated all sections for $\geq 48 \mathrm{~h}$ at $4^{\circ} \mathrm{C}$ in goat antiCTb primary antibody (703; 1:5000; List Biological Laboratories, RRID: AB_10013220) and rabbit anti-c-Fos primary antibody (5348; 1:2000; Cell Signaling Technology, RRID:AB_10557109) diluted in 2\% NHS in PBS-Tx. We washed off unbound primary antibodies with PBS and incubated the sections with donkey anti-goat Alexa Fluor 488 (705-545-147; 1:2000; Jackson ImmunoResearch, RRID:AB_2336933) and donkey antirabbit Alexa Fluor 594 (705-585-147; 1:2000; Jackson ImmunoResearch, RRID:AB_2336933) for 2-4 h in 2\% NHS in PBS-Tx. We then rinsed sections in PBS. These were mounted onto gelatin-coated glass slides, air dried, and coverslipped with Mowiol (Millipore).

\section{Image acquisition and neuronal quantification}

We digitally captured dark-field images of immunoreactive (IR) cells in the different brain areas using an EXi Aqua camera (QImaging) attached to a Zeiss Axio Scope 2 Axio Imager M2. We captured and analyzed the images using iVision (Biovision) at $10 \times$ magnification in a blind manner (inter-rater reliability between X.L. and F.S.: $r=0.83, p<0.05$ ). We identified CTb-IR neurons with fluorescent cytoplasm using the YFP filter and Fos-IR neurons with fluorescent nuclei using the RFP filter. For each rat, we quantified cells in the same hemisphere as the CTb injection (ipsilateral). We analyzed four sections/brain area using the following bregma coordinates: $\mathrm{dmPFC}$ and vmPFC, +3.72 to $+2.76 \mathrm{~mm}$; AI cortex, +3.72 to $+2.76 \mathrm{~mm}$; BLA, -2.04 to $-2.52 \mathrm{~mm}$; AIT-L and AIT-M, -2.28 to $-3.48 \mathrm{~mm}$. For Pf $(-4.08$ to $-4.36 \mathrm{~mm})$, we analyzed $1-2$ sections per rat due to technical reasons related to the fact that we did not originally plan to analyze this brain region and terminated the collection of the brain sections $\sim 1 \mathrm{~mm}$ posterior to the AIT.

\section{Experimental design and statistical analysis}

Experiment 1: effect of incubated Meth seeking on Fos protein expression in afferent projections to the DMS. The goal of Experiment 1 was to identify critical afferent projections into the DMS that are associated with incubated Meth seeking after prolonged withdrawal. We performed intravenous surgeries on two groups of rats $(n=10)$ and trained them for Meth self-administration for $10 \mathrm{~d}$. To demonstrate that incubation had occurred under the experimental parameters of Experiments 1-4, we tested one group of rats $(n=5)$ for relapse in a $2 \mathrm{~h}$ session on withdrawal day 1 , and this group later served as the No-test group on withdrawal day 30 (see below). Next, we injected CTb unilaterally into the DMS of all rats on withdrawal day 15 . On withdrawal day 30 , we tested the rats for relapse (Relapse test; $n=5$ ) or did not test them (No test; $n=5$ ). We anesthetized the rats, perfused them, and extracted the brains of the rats from the Relapse-test group immediately after the $2 \mathrm{~h}$ test session. During the same time, we also perfused and extracted the brains of the rats from the No-test group, which we brought to the perfusion room directly from their home cages. We measured $\mathrm{CTb}$ and Fos protein in the dmPFC, vmPFC, AI cortex, BLA, AIT-L, AIT-M, and Pf. For the analysis of Fos, $\mathrm{CTb}$, and double-labeling of Fos $+\mathrm{CTb}$, we used an experimental design that included the between-subject factor of Test condition (No test, Relapse test).

Experiment 2: effect of AIT-L or AIT-M inactivation on incubation of Meth craving. The goal of Experiment 2 was to examine whether the AIT-L, AIT-M, or both play a causal role in incubation of Meth craving. In our pilot studies, we found that bilateral AIT-L inactivation by muscimol+baclofen at a dose of $3+64 \mathrm{ng}$ in $0.3 \mu \mathrm{l} / \mathrm{side}$ [a "standard" dose used in our previous study ( $\mathrm{Li}$ et al., 2015a) and in many other studies in many brain regions (McFarland and Kalivas, 2001; Peters et al., 2008)] significantly impaired high-rate operant responding for food due to motor deficits (data not shown). Therefore, we first examined the effect of bilateral AIT-L inactivation with ascending doses of muscimol+baclofen $(1+5,2+10,3+15$, and $3+20 \mathrm{ng} / 0.3 \mu \mathrm{l} /$ side $)$ on food selfadministration. We implanted the rats with bilateral guide cannulas $1.7 \mathrm{~mm}$ above the AIT-L $(n=7)$ and used a within-subject experimental design. We conducted all the training and test sessions for the food study at the beginning of the dark cycle. Briefly, we trained the rats to lever press for food pellets for $5 \mathrm{~d}(1 \mathrm{~h} / \mathrm{d})$ before their first test. On the test days, we injected them with either vehicle or different doses of muscimol+baclofen (as described above) $15 \mathrm{~min}$ before the $1 \mathrm{~h}$ food self-administration session. For each dose, we counterbalanced the order of vehicle and muscimol+baclofen injections. We measured the number of food pellets during the test. We retrained rats to self-administer food pellets for 1 or 2 days $(1 \mathrm{~h} / \mathrm{d})$ in between test days to ensure their responding was comparable to their pretest level before the next test. Based on the data from this pilot study (see Results), we determined the maximum dose $(3+15 \mathrm{ng} / 0.3 \mu \mathrm{l} / \mathrm{side})$ that can be used in Experiment 2 without causing motor deficits.

For Experiment 2, we performed intravenous surgeries on four groups of rats $(n=32)$ and implanted them with bilateral guide cannulas $1.7 \mathrm{~mm}$ above the AIT-L or a single guide cannula $1.7 \mathrm{~mm}$ above the AIT-M. We determined the effect of reversible inactivation of the AIT subregions on Meth seeking after 30 withdrawal days. We performed all intracranial injections $15 \mathrm{~min}$ before the $3 \mathrm{~h}$ relapse tests. For the AIT-L groups, we injected vehicle $(n=8)$ or muscimol+baclofen $(n=9)$ bilaterally. For the AIT-M inactivation group, we injected vehicle $(n=7)$ or muscimol + baclofen $(n=$ 8) via a single cannula.

Experiment 3: effect of ipsilateral and contralateral disconnection of the DMS and AIT-L on incubation of Meth craving. The goal of Experiment 3 was to determine whether synergetic activation of the AIT $\rightarrow$ DMS glutamatergic projections and DMS D1Rs plays a role in incubation of Meth craving (see Introduction). We performed intravenous surgeries on four groups of rats (total $n=39$ ) and implanted each rat with two unilateral cannulas $1 \mathrm{~mm}$ above the DMS and $1.7 \mathrm{~mm}$ above the AIT-L, respectively. These two unilateral cannulas were either in the same hemisphere (ipsilateral) or in opposite hemispheres (contralateral). We counterbalanced the left and right hemispheres for cannula implantation in Experiment 3 (and Exps. 4 and 5). We then trained the rats for Meth self-administration in four independent runs and used a $2 \times 2$ between-subjects factorial design of drug condition (vehicle vs SCH23390 and muscimol + baclofen) $\times$ disconnection condition (ipsilateral vs contralateral). We determined the effect of ipsilateral and contralateral disconnection of the DMS and AIT-L on Meth seeking after 30 withdrawal days. We performed all intracranial injections $15 \mathrm{~min}$ before the $3 \mathrm{~h}$ relapse tests. For the two vehicle groups $(n=18)$, we injected vehicle into the DMS and AIT-L and combined these two groups [ipsilateral $(n=9)$ or contralateral $(n=9)$ injections] for the statistical analysis. For the ipsilateral group $(n=10)$, we injected SCH23390 unilaterally into the DMS of one hemisphere and muscimol+baclofen unilaterally into the AIT-L of the same hemisphere. For the contralateral disconnection group $(n=11)$, we injected SCH23390 unilaterally into the DMS of one hemisphere and muscimol+baclofen unilaterally into the AIT-L of the opposite hemisphere.

To examine whether ipsilateral or contralateral disconnection of AIT $\rightarrow$ DMS projections causes motor deficits (assessed by ongoing food self-administration), we implanted cannulas into an independent cohort of rats $(n=6$; bilateral cannula $1 \mathrm{~mm}$ above the DMS and unilateral cannula $1.7 \mathrm{~mm}$ above the AIT-L) and we used a within-subject experimental design. We conducted all the training and test sessions for the food study $6-8 \mathrm{~h}$ after the onset of the dark cycle. We trained the rats to lever press for food pellets for $5 \mathrm{~d}(1 \mathrm{~h} / \mathrm{d})$ before their first test. During the first set of tests, we injected them with vehicle or drug (SCH23390 uni- 
laterally into the DMS, muscimol+baclofen unilaterally into the contralateral AIT-L) $15 \mathrm{~min}$ before the $1 \mathrm{~h}$ food self-administration session. During the second set of tests, we injected them with vehicle or drug (SCH23390 unilaterally into the DMS, muscimol + baclofen unilaterally into the ipsilateral AIT-L) $15 \mathrm{~min}$ before the $1 \mathrm{~h}$ food self-administration session. We counterbalanced the order of vehicle and muscimol+baclofen injections on 2 separate test days. We measured the number of food pellets during the test. We retrained the rats to self-administer food pellets for 1 or $2 \mathrm{~d}(1 \mathrm{~h} / \mathrm{d})$ in between the test days to ensure their responding was comparable to pretest level before the next test.

Experiment 4: effect of unilateral inactivation of the DMS or AIT-L on incubation of Meth craving. In Experiment 3, we found that both the ipsilateral and contralateral disconnection manipulations decreased incubated Meth seeking after 30 withdrawal days. Based on these results, the goal of Experiment 4 was to rule out the possibility that unilateral inactivation of the DMS or AIT-L is sufficient to decrease incubation of Meth craving. We performed intravenous surgeries on four groups of rats (total $n=34$ ) and implanted each rat with bilateral cannulas $1 \mathrm{~mm}$ above the DMS or $1.7 \mathrm{~mm}$ above the AIT-L, respectively. We then trained the rats for Meth self-administration and determined the effect of unilateral inactivation of the DMS or AIT-L on Meth seeking after 30 withdrawal days. We performed all intracranial injections 15 min before the $3 \mathrm{~h}$ relapse tests. For the two vehicle groups $(n=16)$, we injected vehicle bilaterally into the DMS $(n=8)$ or the AIT-L $(n=8)$. For the drug group, we injected either SCH 23390 unilaterally into the DMS $(n=9)$ or muscimol+baclofen unilaterally into the AIT-L $(n=9)$, and the opposite hemisphere received a vehicle injection. For each brain area, we used an experimental design that included between-subjects factor of drug condition (vehicle vs SCH23390 or muscimol+baclofen.

Experiment 5: effect of contralateral disconnection of AIT- $L \rightarrow D M S$ projections on Meth seeking on withdrawal day 1. The goal of Experiment 5 was to determine whether AIT-L $\rightarrow$ DMS projections play a specific role in incubated Meth seeking after prolonged withdrawal (day 30) versus a general time-independent role in Meth seeking. We performed intravenous surgeries on two groups of rats (total $n=17$ ) and implanted each rat with two unilateral cannulas, one $1 \mathrm{~mm}$ above the DMS and the other $1.7 \mathrm{~mm}$ above the AIT-L. These two unilateral cannulas were in opposite hemispheres (contralateral). Next, we trained the rats for Meth selfadministration and then determined the effect of contralateral disconnection of the DMS and AIT-L on Meth seeking on withdrawal day 1. We performed all intracranial injections $15 \mathrm{~min}$ before the $3 \mathrm{~h}$ relapse tests. We used a between-subjects factorial design that included the factor of Drug condition (vehicle vs SCH23390 and muscimol+baclofen). For the vehicle group $(n=7)$, we injected vehicle into the DMS and AIT-L. For the contralateral disconnection group $(n=10)$, we injected SCH23390 unilaterally into the DMS of one hemisphere and muscimol+baclofen unilaterally into the AIT-L of the opposite hemisphere.

\section{Statistical analysis}

We analyzed the behavioral and anatomical data with SPSS (version 24) using factorial ANOVAs. We followed significant interaction or main effects $(p<0.05)$ with Fisher PLSD post hoc tests. We indicate the between-subjects and within-subject factors of the different analyses in the Results.

\section{Results}

\section{Meth self-administration}

As in our previous studies (Li et al., 2015a,b), during the training phase the rats demonstrated reliable escalation of Meth selfadministration and a strong preference for the Meth-paired active lever over the inactive lever (Exps. 1-5; Fig. 1A-E).

\section{Experiment 1: effect of incubated Meth seeking on Fos expression in afferent projections to the DMS}

The goal of Experiment 1 was to identify activated projections into the DMS during Meth seeking after prolonged withdrawal. For this purpose, we measured the double-labeling of retrograde tracer $\mathrm{CTb}$ and Fos in several projection areas after the relapse test on withdrawal day 30 .

\section{Relapse tests}

Meth seeking in the relapse tests (Fig. 2C,D) was higher after 30 withdrawal days than after $1 \mathrm{~d}$, demonstrating "incubation of Meth craving" under our experimental conditions. We analyzed the data with the between-subjects factor of Withdrawal day (Day 1, Day 30) and within-subjects factor of Lever (active lever, inactive lever). We observed a significant interaction between the two factors $\left(F_{(1,8)}=36.0, p<0.001\right.$; Fig. $\left.2 C\right)$. Analysis of the time course (30 min interval) of lever presses showed a significant triple interaction between Withdrawal day, Session minutes, and Lever $\left(F_{(3,24)}=8.4, p=0.001\right.$; Fig. $\left.2 D\right)$.

\section{Fos data}

Exposure to the relapse test on withdrawal day 30 was associated with a significant increase in Fos expression in the dmPFC, vmPFC, AI cortex, BLA, and AIT-L, but not in the AIT-M or Pf (Fig. 2E). The ANOVA of each brain region showed a significant effect of test condition for the $\operatorname{dmPFC}\left(F_{(1,9)}=21.2, p=0.002\right)$, $\operatorname{vmPFC}\left(F_{(1,9)}=7.3, p=0.027\right)$, AI cortex $\left(F_{(1,9)}=233.8, p<\right.$ $0.001)$, BLA $\left(F_{(1,9)}=11.7, p=0.009\right)$, and AIT-L $\left(F_{(1,9)}=25.4\right.$, $p=0.001)$. The effect of test condition for the AIT-M $\left(F_{(1,9)}=\right.$ $4.6, p=0.063)$ and $\operatorname{Pf}\left(F_{(1,9)}=2.3, p=0.165\right)$ was not statistically significant.

\section{$\mathrm{CTb}$ and $\mathrm{CTb}+$ Fos data}

We observed no differences in total number of CTb-IR cells between the groups across brain regions ( $p$ 's $>0.05$; Fig. $2 F$ ). Analysis of CTb+Fos-IR double-labeled cells (Fig. 2G) showed a significant test condition effect for the AIT-L $\left(F_{(1,9)}=9.5, p=\right.$ $0.015)$ and the AIT-M $\left(F_{(1,9)}=5.9, p=0.041\right)$, but not for the $\operatorname{dmPFC}\left(F_{(1,9)}=4.3, p=0.073\right)$, the $\operatorname{vmPFC}\left(F_{(1,9)}=2.9, p=\right.$ $0.126)$, the BLA $\left(F_{(1,9)}=1.0, p=0.359\right)$, or the Pf $\left(F_{(1,9)}=0.6\right.$, $p=0.817)$. We did not perform statistical analysis on the AI cortex double-labeling data because the number of doublelabeled neurons was too low (zero in No-test group and 1-2 neurons in Relapse test group) for a meaningful statistical analysis.

\section{Summary}

The data in Experiment 1 demonstrated that all brain regions examined except for the AIT-M and Pf were activated during the test for incubated Meth seeking. More importantly, the $\mathrm{CTb}+$ Fos double-labeling data showed that incubated Meth seeking was associated with selective activation of AIT-L and AIT-M neurons that project to the DMS.

\section{Experiment 2: effect of AIT-L or AIT-M inactivation on incubation of Meth craving}

The goal of Experiment 2 was to determine whether the AIT-L, AIT-M, or both play a causal role in incubated Meth seeking. For this purpose, we first examined the effect of bilateral inactivation of the AIT-L of ascending doses of muscimol+baclofen $(1+5$, $2+10,3+15$, and $3+20 \mathrm{ng} / 0.3 \mu \mathrm{l} /$ side $)$ on food selfadministration, and determined the maximum AIT-Linjection dose of muscimol+baclofen that can be used in Experiment 2 without causing motor deficits. Then we measured Meth seeking after 30 withdrawal days after injections of vehicle or muscimol+baclofen into the two AIT subregions.

\section{Effect of AIT-L inactivation on food self-administration}

We found that AIT-L injection doses of muscimol+baclofen up to $3+15 \mathrm{ng} / 0.3 \mu \mathrm{l} /$ side had no effect on operant responding 


\section{A Timeline}

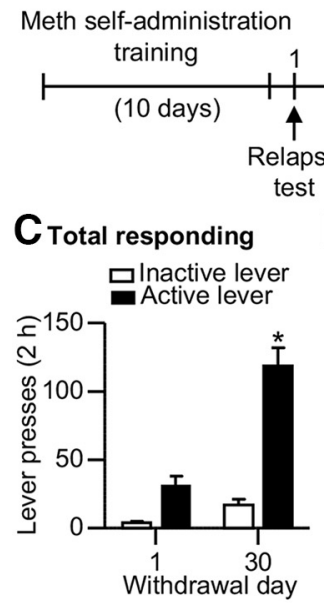

\section{E Fos-IR neurons}

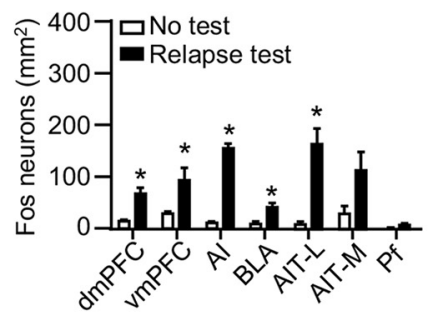

H Representative $\mathrm{CTb}+\mathrm{Fos}$ images

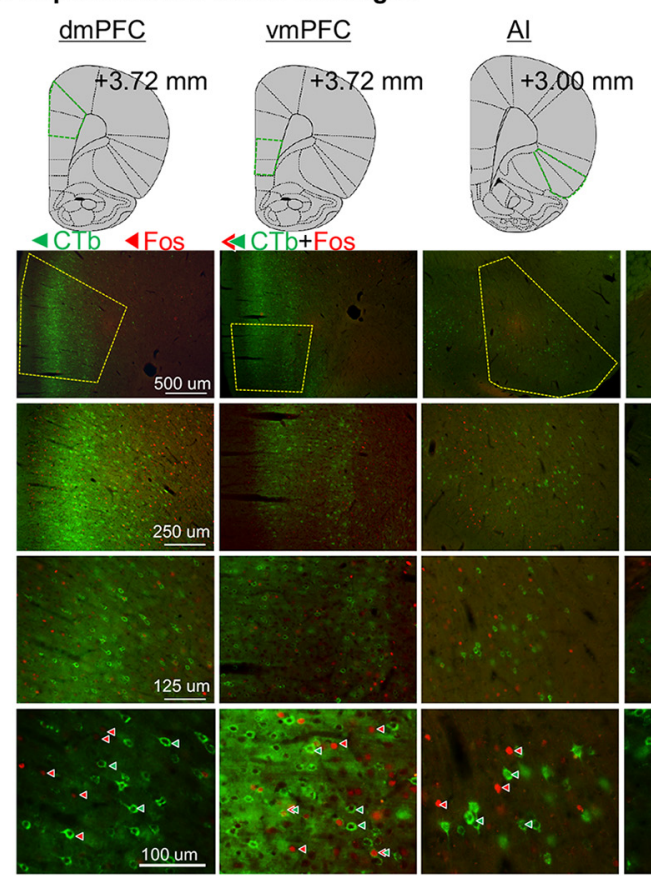

Withdrawal period

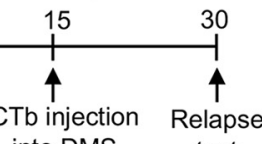

D Time course

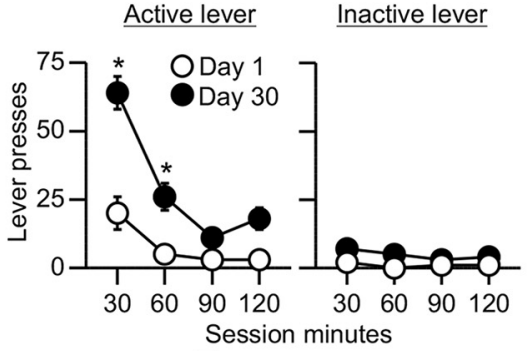

$\mathbf{F}$ cTb-IR neurons

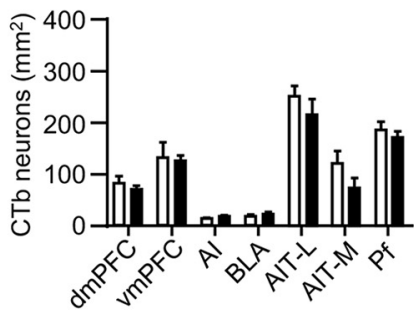

B CTb injection into DMS
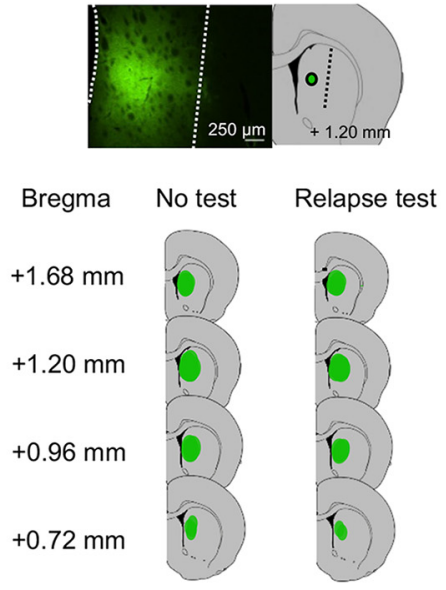

G cTb+Fos-IR neurons

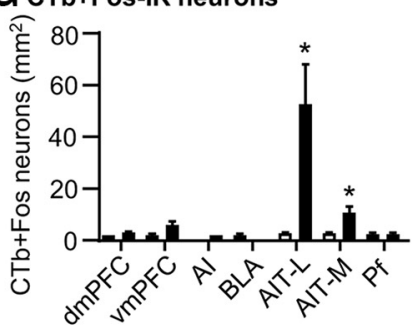




\section{A Timeline}
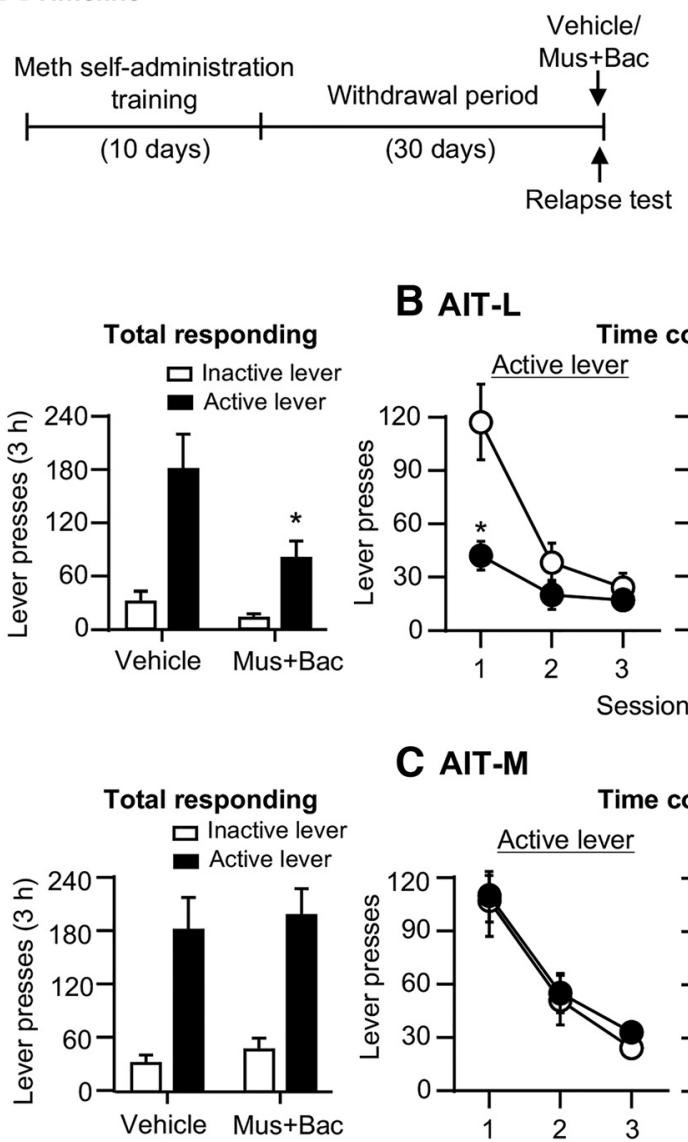

B AIT-L

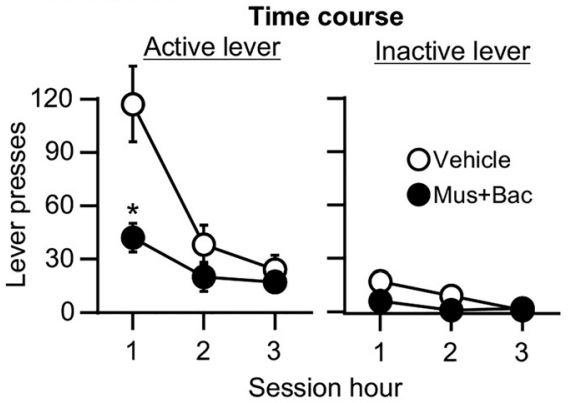

C AIT-M

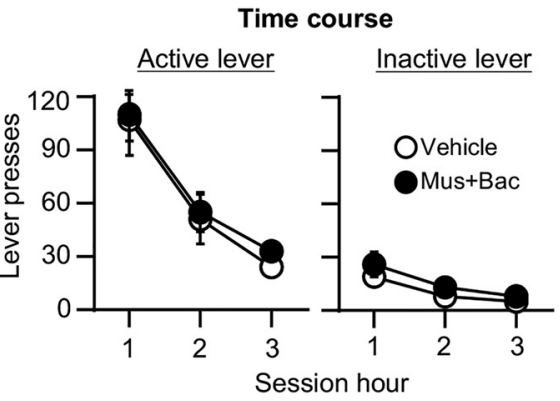

D Cannula placements

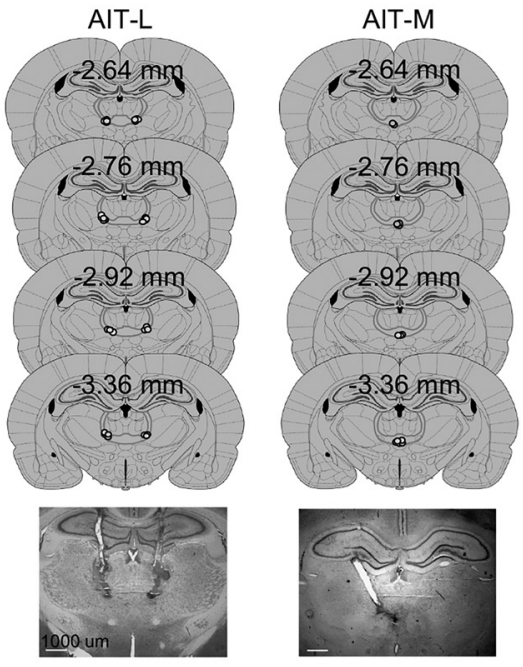

Figure 3. Inactivation of AIT-L, but not AIT-M, decreased incubated Meth seeking (Exp. 2). A, Timeline of the experiment. B, C, AIT-L: relapse tests after 30 withdrawal days after vehicle ( $n=8$ ) or muscimol + baclofen $(3+15 \mathrm{ng} / 0.3 \mu \mathrm{l} /$ side) injections; $n=9$. AlT-M: relapse tests after 30 withdrawal days after vehicle $(n=7)$ or muscimol + baclofen $(3+15 \mathrm{ng} / 0.3 \mu \mathrm{l} / \mathrm{side}, n=8)$ injections. Data are mean \pm SEM of responses on the previously active lever or inactive lever during the relapse tests. * , Different from vehicle, $p<0.05$. D, Approximate placement [mm from bregma (Paxinos and Watson, 2005)] of injection tips (vehicle: open circles; muscimol + baclofen: closed circles), and representative cannula placements. See Figure 3-1, available at https://doi.org/10.1523/JNEUROSCI.2873-17.2018.f3-1.

self-administration behavior in two rats, due to observed sedative effects. Based on these observations, we chose the dose of $3+15$ $\mathrm{ng} / 0.3 \mu \mathrm{l} /$ side for Experiment 2.

\section{Relapse tests}

Muscimol+baclofen injections into the AIT-L, but not into the AIT-M, decreased Meth seeking after 30 withdrawal days (Fig. $3 B, C)$. The analysis, which included the between-subjects factor of Drug dose (muscimol+baclofen: 0, $3+15 \mathrm{ng} /$ side) and the within-subjects factor of Lever (active lever, inactive lever), showed a main effect of drug dose for the AIT-L $\left(F_{(1,15)}=7.1, p=\right.$ $0.018)$, but not the AIT-M $\left(F_{(1,13)}=0.3, p=0.571\right)$, and a main effect of Lever for both the AIT-L $\left(F_{(1,15)}=29.6, p<0.001\right)$ and the AIT-M $\left(F_{(1,13)}=64.1, p<0.001\right)$, but no significant interaction between the two factors (AIT-L: $F_{(1,15)}=4.3, p=0.057$; AIT-M: $\left.F_{(1,13)}=0.0, p=0.99\right)$. We also analyzed the time course ( $1 \mathrm{~h}$ interval) of lever presses by using the between-subjects factor of Drug dose, and the within-subject factors of Lever and Session hour $(1,2,3 \mathrm{~h})$. We observed a significant triple interaction (Drug dose $\times$ Lever $\times$ Session hour $)$ for AIT-L groups $\left(F_{(2,30)}=\right.$ 15.9; $p<0.001$; Fig. $3 B)$ but not AIT-M $\left(F_{(2,26)}=0.3, p=0.755\right.$; Fig. $3 C$ ). The time course analyses also showed a significant interaction between Drug dose $\times$ Session hour for the AIT-L $\left(F_{(2,30)}=14.0 ; p<0.001\right)$ but not the AIT-M $(p=0.994)$. We indicate Fisher PLSD post hoc group differences in Figure $3 B, C$. Finally, we analyzed the data of the rats excluded due to misplaced cannulas. There were no significant group differences between the excluded vehicle $(n=11)$ and excluded muscimol+baclofen $(n=13)$ rats: means \pm SEM $118 \pm 38$ versus $172 \pm 32$ active lever presses $/ 3 \mathrm{~h}$, respectively.

\section{Summary}

The data in Experiment 2 indicate that reversible inactivation of the AIT-L, but not the AIT-M, decreased incubated Meth seeking after prolonged withdrawal.

\section{Experiment 3: effect of ipsilateral and contralateral} disconnection of the DMS and AIT-L on incubation of Meth craving

The goal of Experiment 3 was to determine whether synergetic activation of the AIT $\rightarrow$ DMS glutamatergic projections and DMS D1Rs plays a role in incubation of Meth craving (see Introduction). For this purpose, we used a variation of a reversible asymmetric pharmacological inactivation procedure, in which we inhibited the glutamatergic cell bodies in the AIT-L unilaterally using muscimol+baclofen while simultaneously inhibiting postsynaptic D1Rs in the DMS by SCH23390 in either the ipsilateral or contralateral hemisphere. 


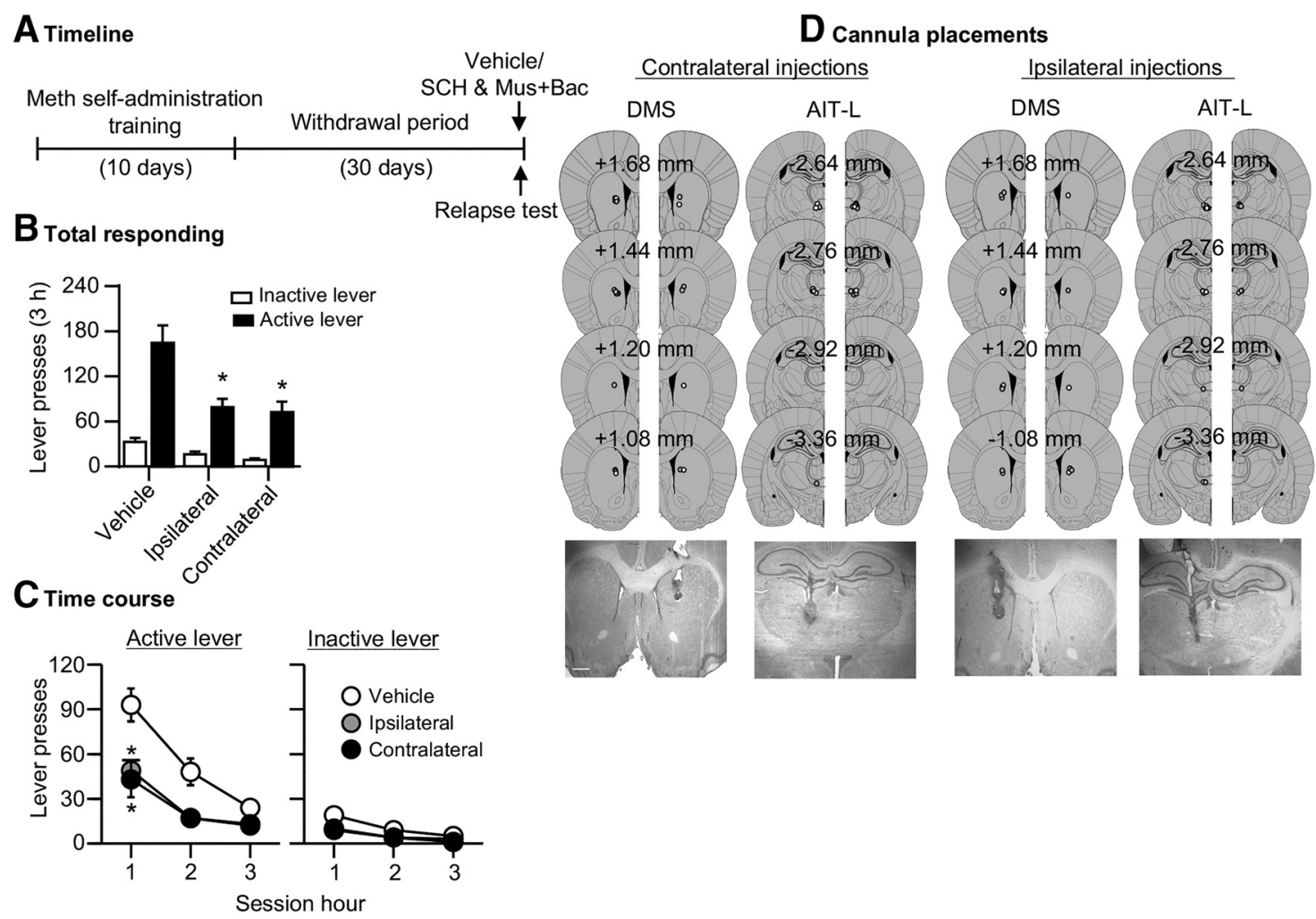

Figure 4. Anatomical disconnection of the AIT-L and the DMS decreased incubated Meth seeking (Exp. 3). $A$, Timeline of the experiment. $\boldsymbol{B}, \boldsymbol{C}$, Relapse tests after 30 withdrawal days after unilateral injection of vehicle or muscimol + baclofen $(3+15 \mathrm{ng} / 0.3 \mu \mathrm{l} / \mathrm{side})$ into the AIT-L, and contralateral or ipsilateral injection of vehicle or SCH23390 $(0.75 \mu \mathrm{g} / 0.5 \mu \mathrm{l} / \mathrm{side})$ into the DMS (vehicle, $n=18$; ipsilateral inactivation, $n=10$; contralateral inactivation, $n=11$ ). Data are mean \pm SEM of responses on the previously active lever or inactive lever during the relapse tests. *, Different from vehicle, $p<0.05$. D, Approximate placement [mm from bregma (Paxinos and Watson, 2005)] of injection tips (vehicle: open circles; muscimol + baclofen or SCH23390: closed circles), and representative cannula placements. See Figure 4-1, available at https://doi.org/10.1523/JNEUROSCI.2873-17.2018.f4-1.

\section{Relapse tests}

Both contralateral and ipsilateral disconnection of the AIT-L (unilateral injection of muscimol+baclofen) and the DMS (unilateral injection of SCH23390) decreased Meth seeking after 30 withdrawal days. The analysis, which included the betweensubjects factor of Group [vehicle (ipsilateral and contralateral combined), ipsilateral disconnection, contralateral disconnection] and the within-subjects factor of Lever, showed a significant interaction between the two factors $\left(F_{(2,36)}=4.6, p=0.017\right.$; Fig. $4 B)$. We also analyzed the time course ( $1 \mathrm{~h}$ interval) of lever presses by using the between-subjects factor of Group and the within-subject factors of Lever and Session hour. We observed a significant interaction between the three factors $\left(F_{(4,72)}=3.2\right.$, $p=0.017$; Fig. $4 C)$ and a significant interaction between Group and Session hour $\left(F_{(4,72)}=3.9 ; p=0.006\right)$. We indicated Fisher PLSD post hoc group differences in Figure $4 C$. Finally, we also analyzed the data of the rats excluded due to misplaced cannulas. There were no significant group differences between the excluded vehicle $(n=8)$ and excluded SCH23390 and muscimol+baclofen $(n=24)$ rats (means \pm SEM: $119 \pm 31$ vs $130 \pm 17$ active lever presses $/ 3 \mathrm{~h}$, respectively).

\section{Summary}

The data in Experiment 3 indicate that the AIT-L $\rightarrow$ DMS projections play a critical role in incubation of Meth craving. Several factors may contribute to the similar effect of contralateral and ipsilateral AIT-L $\rightarrow$ DMS disconnection on incubated Meth seeking (see Discussion). One possibility is that contralateral or ipsilateral AIT-L $\rightarrow$ DMS disconnection causes motor deficits. However, we found that neither contralateral nor ipsilateral
AIT-L $\rightarrow$ DMS disconnection impaired food self-administration. The number of food pellets (means \pm SEM) during the $1 \mathrm{~h}$ test session were $143 \pm 5$ and $150 \pm 9$ after vehicle injection, and $126 \pm 11$ and $147 \pm 5$ after muscimol + baclofen injections for the contralateral $\left(F_{(1,5)}=1.9, p=0.226\right)$ and ipsilateral $\left(F_{(1,5)}=0.1\right.$, $p=0.756$ ) inactivation manipulations, respectively (Fig. 4-1, available at https://doi.org/10.1523/JNEUROSCI.2873-17.2018.f4-1). Another possibility is that unilateral inactivation of the DMS or AIT-L is sufficient to decrease incubated Meth seeking. To test this possibility, we performed Experiment 4.

\section{Experiment 4: effect of unilateral inactivation of the DMS or AIT-L on incubation of Meth craving}

The goal of Experiment 4 was to determine whether unilateral inactivation of the DMS or AIT-L is sufficient to decrease incubated Meth seeking after prolonged withdrawal. For this purpose, we measured Meth seeking during relapse tests after 30 withdrawal days after unilateral injection of vehicle or SCH23390 into the DMS or of vehicle or muscimol+baclofen into the AIT-L in four groups of rats.

\section{Relapse tests}

Neither unilateral inactivation of the AIT-L or the DMS had any effect on incubated Meth seeking after 30 withdrawal days (Fig. $5 B, C)$. The statistical analysis, which included the betweensubjects factor of Drug dose (muscimol+baclofen: $0,3+15$ $\mathrm{ng} /$ side; or SCH23390: 0, $0.75 \mu \mathrm{g} /$ side) and the within-subjects factor of Lever, showed a significant effect of Lever (AIT-L: $F_{(1,15)}=$ 44.6, $p<0.001$; DMS: $\left.F_{(1,15)}=102.8 p<0.001\right)$, but no effects of 


\section{A Timeline}

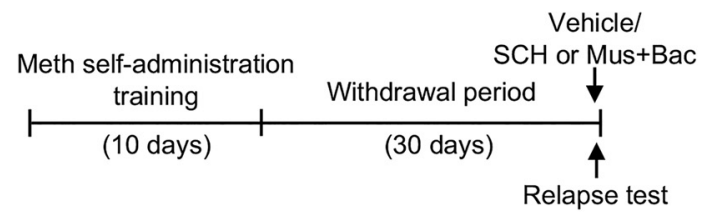

B Total responding

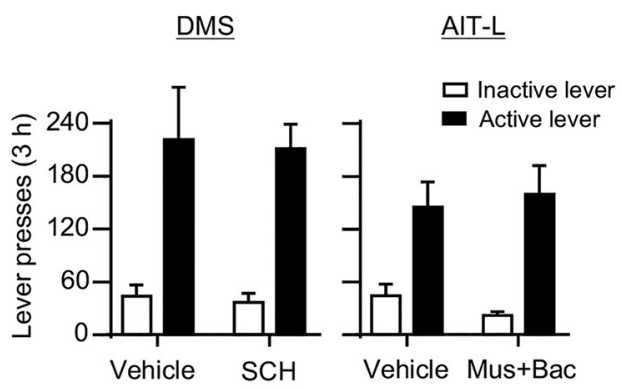

\section{Time course}

DMS

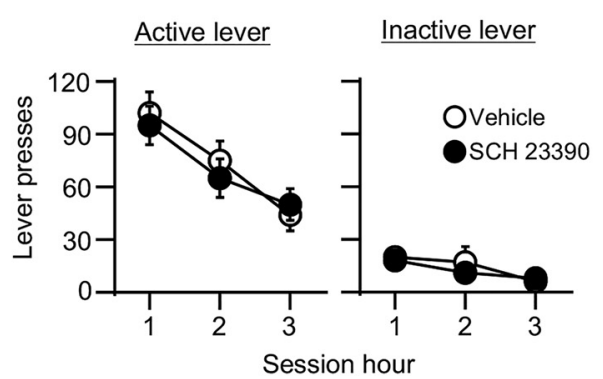

D Cannula placements
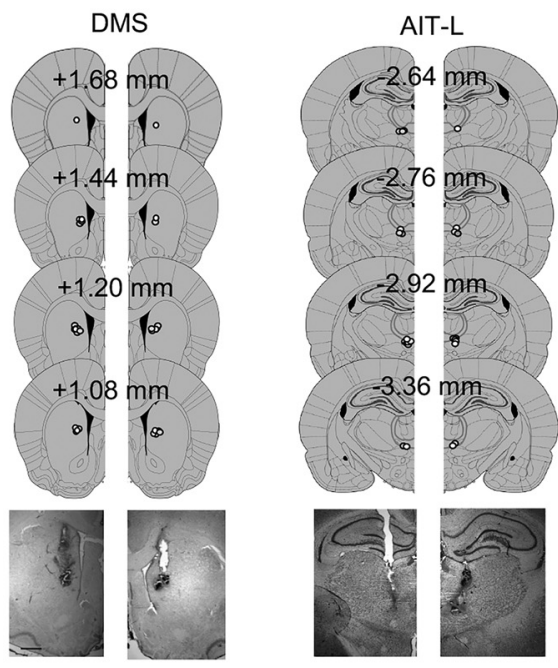

AIT-L

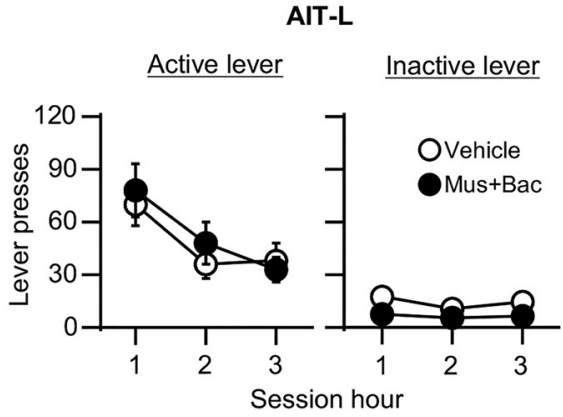

Figure 5. Unilateral inactivation of the AIT-L or the DMS had no effect on incubated Meth seeking (Exp. 4). $A$, Timeline of the experiment. $B, C$, DMS: relapse tests after 30 withdrawal days after unilateral vehicle $(n=8)$ or SCH23390 injection $(0.75 \mu \mathrm{g} / 0.5 \mu \mathrm{l} / \mathrm{side} ; n=9)$. AlT-L: relapse tests after 30 withdrawal days after unilateral vehicle $(n=8)$ or muscimol + baclofen injections $(3+$ $15 \mathrm{ng} / 0.3 \mu \mathrm{l} / \mathrm{side} ; n=9)$. Data are mean \pm SEM of responses on the previously active lever or inactive lever during the relapse tests. $\boldsymbol{D}$, Approximate placement [mm from bregma (Paxinos and Watson, 2005)] of injection tips (vehicle: open circles; muscimol + baclofen or SCH23390: closed circles), and representative cannula placements.

the Drug dose (AIT-L: $F_{(1,15)}=0.0, p=0.88$; DMS: $F_{(1,15)}=0.1$, $p=0.72)$ or an interaction between the two factors ( $p$ 's $>0.1)$. The analysis of the time course data, using the between-subjects factor of Drug dose, and the within-subjects factors of Lever and Session hour, did not show significant interactions between the two factors $(p$ 's $>0.1)$.

\section{Summary}

The data in Experiment 4 showed that unilateral inactivation of the AIT-L or D1R blockade of DMS had no effect on incubated Meth seeking.

\section{Experiment 5: effect of contralateral disconnection of} AIT-L $\rightarrow$ DMS projections on Meth seeking on withdrawal day 1

The goal of Experiment 5 was to determine whether AIT-L $\rightarrow$ DMS projections play a specific role in incubated Meth seeking after prolonged withdrawal (day 30) versus a general time-independent role in Meth seeking. For this purpose, we used the asymmetric pharmacological inactivation procedure (as described in Exp. 3) and examined the effect of contralateral disconnection of the AIT-L $\rightarrow$ DMS projection on nonincubated Meth seeking on withdrawal day 1 (Fig. 2B).
Relapse tests

Contralateral disconnection of AIT-L $\rightarrow$ DMS projections had no effect on Meth seeking on withdrawal day 1 (Fig. 6B,C). The statistical analysis, which included the between-subjects factor of Drug dose [vehicle vs SCH23390 (0.75 $\mu \mathrm{g} / \mathrm{side})$ and muscimol+baclofen $(3+15 \mathrm{ng} /$ side $)]$ and the within-subjects factor of Lever, showed a significant effect of Lever $\left(F_{(1,15)}=15.4\right.$, $p<0.001)$ but no effect of Drug dose $\left(F_{(1,15)}=0.7, p=0.789\right)$ or an interaction between the two factors $\left(F_{(1,15)}=0.2, p=0.637\right)$. The analysis of the time course data, using the between-subjects factor of Drug dose and the within-subjects factors of Lever and Session hour showed significant main effects of Session hour $\left(F_{(2,30)}=11.3, p<0.001\right)$ and Lever $\left(F_{(1,15)}=9.4, p=0.008\right)$, but not of Drug dose or interactions between the different factors $\left(p^{\prime} s>0.1\right)$.

\section{Summary}

The data in Experiment 5 showed that contralateral disconnection of AIT-L $\rightarrow$ DMS projections had no effect on nonincubated Meth seeking on withdrawal day 1 . Together with the results of Experiment 3, these results demonstrate a specific role of AIT-L $\rightarrow$ DMS projections on incubated Meth seeking after prolonged withdrawal. 


\section{A Timeline}

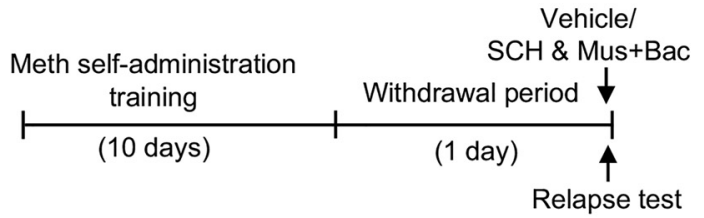

\section{B Total responding}

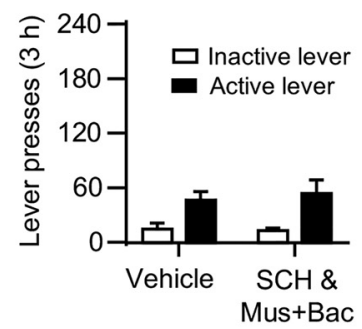

\section{Time course}

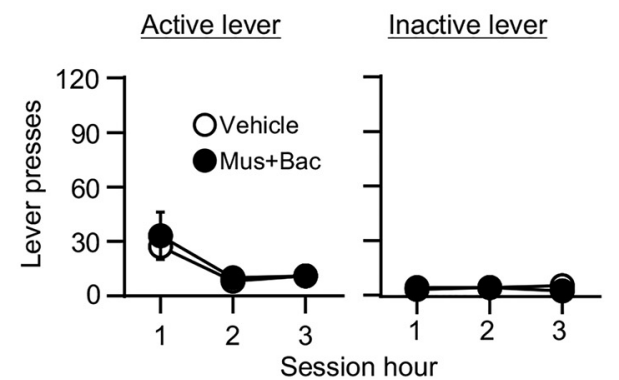

D Cannula placements
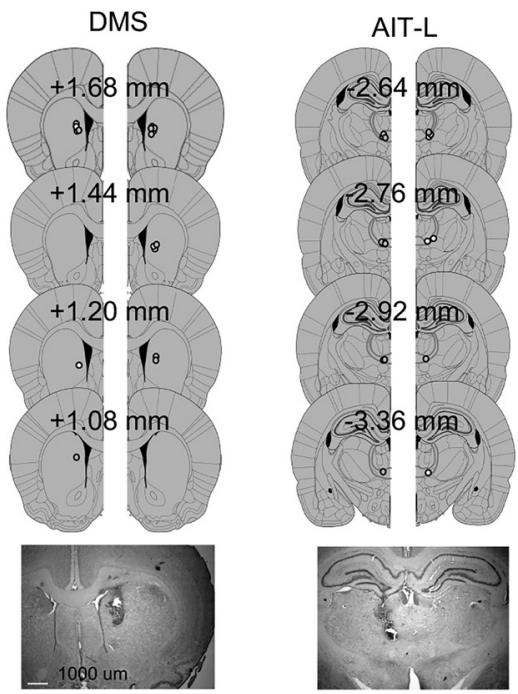

Figure 6. Contralateral disconnection of the AIT-L and the DMS had no effect on Meth seeking on withdrawal day 1 (Exp. 5$)$. $A$, Timeline of the experiment. $B, C$, Relapse test on withdrawal day 1 after unilateral injection of vehicle or muscimol + baclofen $(3+15 \mathrm{ng} / 0.3 \mu \mathrm{l} / \mathrm{side})$ into the AIT-L, and contralateral injection of vehicle or SCH23390 ( $0.75 \mu \mathrm{g} / 0.5 \mu \mathrm{l} / \mathrm{side})$ into the DMS (vehicle, $n=7$; contralateral inactivation, $n=10$ ). Data are mean \pm SEM of responses on the previously active lever or inactive lever during the relapse tests. $D$, Approximate placement [mm from bregma (Paxinos and Watson, 2005)] of injection tips (vehicle: open circles; muscimol + baclofen or SCH23390: closed circles), and representative cannula placements.

\section{Discussion}

We studied the role of afferent glutamatergic projections into the DMS and their interaction with local D1R-mediated neurotransmission in incubation of Meth craving. We report three major findings. First, Meth seeking after prolonged withdrawal (30 d) was associated with selective activation (assessed by doublelabeling of $\mathrm{CTb}+$ Fos $)$ of the AIT-L $\rightarrow$ DMS and AIT-M $\rightarrow$ DMS projections. Second, muscimol+baclofen injections into the AIT-L but not the AIT-M decreased incubated Meth seeking. Third, ipsilateral or contralateral disconnection of the AIT-L $\rightarrow$ DMS projection (inhibition of AIT-L cell bodies with muscimol+baclofen in one hemisphere plus blockade of D1R in DMS with SCH23390 in either the contralateral of ipsilateral hemisphere) decreased the incubated drug-seeking response. In contrast, unilateral muscimol+baclofen injection into the AIT-L or unilateral SCH23390 injection into the DMS had no effect on incubated drug seeking. Finally, contralateral disconnection of the AIT-L $\rightarrow$ DMS projection had no effect on nonincubated Meth seeking on withdrawal day 1 . Based on these findings, we propose that an interaction between AIT-L glutamatergic projections and local D1R-mediated transmission in the DMS is critical to incubation of Meth craving.

\section{Methodological considerations}

One issue is that the effect of the pharmacological manipulations was due to motor deficits. This possibility is unlikely because neither AIT-L inactivation nor AIT-L $\rightarrow$ DMS disconnection decreased high-rate food-reinforced responding (Fig. $3 A$ and Fig. $4 A$ ); additionally, AIT-L $\rightarrow$ DMS contralateral disconnection had no effect on Meth seeking on withdrawal day 1 . A second issue is the anatomical specificity of the AIT-L intracranial injections due to muscimol+baclofen diffusion to adjacent sites (e.g., mediodorsal thalamus). While this possibility cannot be ruled out, we believe it is unlikely because we found that muscimol+baclofen injections that missed the AIT-L or drug mixture injections that selectively targeted the AIT-M had no effect on incubated Meth seeking. A third issue is the degree to which the role of the AIT-L $\rightarrow$ DMS projection is selective to incubated Meth seeking after prolonged withdrawal or whether this projection also plays a role in nonincubated Meth seeking during early withdrawal. The observation that disconnection of the AIT-L $\rightarrow$ DMS projection had no effect on Meth seeking on withdrawal day 1 suggests a selective role of this projection in incubated Meth seeking.

A fourth issue is the role of the AIT-M and AIT-M $\rightarrow$ DMS projection in incubation of Meth craving. In this regard, we did not perform a pilot dose-response study to determine the optimal dose for inactivating the AIT-M by muscimol+ baclofen without impairing operant responding. Therefore, our negative data on the effect of bilateral AIT-M inactivation (Fig. 3) do not rule out a potential role of the AIT-M in this incubation. Additionally, we did not test the role of this pro- 
jection in incubated Meth seeking on withdrawal day 30 . Thus, the role of the AIT-M $\rightarrow$ DMS projection in incubation of Meth craving is unknown. Another issue is the role of other DMS afferent projections in this incubation. The Fos-CTb doublelabeling data in Experiment 2 were negative but negative data with Fos as the neuronal activity marker do not rule out a critical role of a given brain area and its projections in behavior. Thus, a question for future studies is whether the other DMS projections, which were not activated in our anatomical tracing study, would also play a role in incubation of Meth craving.

Perhaps the main issue in our study is how to interpret the similar inhibitory effect of the contralateral and ipsilateral disconnection of the AIT-L $\rightarrow$ DMS projections. The classic asymmetrical disconnection procedure is based on the premise that neuronal projections are primarily ipsilateral and that learned behaviors can be maintained by the intact hemisphere (Gaffan et al., 1993; Floresco et al., 1997; Setlow et al., 2002). Therefore, a role of a putative serial neuronal pathway in learned behaviors is inferred when behavior is disrupted by the contralateral but not the ipsilateral manipulation (Gaffan et al., 1993; Setlow et al., 2002). However, we found that ipsilateral manipulations of AIT-L $\rightarrow$ DMS projections also decreased incubated Meth seeking, a pattern of results that is in agreement with previous studies showing that contralateral and ipsilateral disconnections of corticostriatal, hippocampal-striatal, or corticoamygdala projections had similar effects on drug seeking (Fuchs et al., 2007; Peters et al., 2008; Lasseter et al., 2011; Bossert et al., 2012, 2016). What might account for the similar effects of the ipsilateral and contralateral manipulations in our study?

One interpretation is that unilateral AIT-L activity or unilateral D1R-mediated activity in the DMS is critical for incubated Meth seeking. However, this possibility is unlikely because unilateral inactivation of the AIT-L or unilateral inhibition of D1Rs in the DMS had no effect on incubated Meth seeking. Another interpretation is that both contralateral and ipsilateral anatomical projections from the AIT-L to the DMS are critical for incubated Meth seeking. This possibility is also unlikely because we found selective ipsilateral labeling of the AIT-L after either unilateral CTb or the retrograding virus (scAAV2-retro-eGFP; Tervo et al., 2016) injection into the DMS (Fig. 2-1, available at https:// doi.org/10.1523/JNEUROSCI.2873-17.2018.f2-1).

Another possibility is that both the AIT-L and the DMS communicates with an additional brain region and consequently either contralateral or ipsilateral manipulations of AIT-L $\rightarrow$ DMS projections disrupt these communications. One such potential brain region is the $\mathrm{dmPFC}$, which receives projections from paracentral thalamus and projects to the DMS (Van der Werf et al., 2002). However, this possibility is unlikely, because we previously found that reversible inactivation of dmPFC had no effect on incubated Meth seeking (Li et al., 2015a).

A potential interpretation of our results is that coordinated activity of ipsilateral projections from both hemispheres is critical to drug seeking and, consequently, an intact ipsilateral projection from one hemisphere is insufficient to maintain some forms of operant drug seeking (Crombag et al., 2008). This interpretation can account for the present data, as well as for results from previous studies on the similar effects of different ipsilateral and contralateral disconnection manipulations on drug seeking (Fuchs et al., 2007; Peters et al., 2008; Lasseter et al., 2011; Bossert et al., 2012, 2016).

\section{Role of the AIT-L and AIT-L $\rightarrow$ DMS projections in incubated Meth seeking}

The main findings in our study are that AIT-L and AIT $\rightarrow$ DMS projections are critical for incubated Meth seeking. To our knowledge, this brain region and projection has not been previously studied within the context of drug reward and relapse. Thus, we can only speculate about how their inactivation might inhibit Meth seeking. We propose below three ideas, which are of course not mutually exclusive.

First, the AIT has been implicated in arousal and awareness (Groenewegen and Berendse, 1994; Van der Werf et al., 2002; Schiff, 2008; Pereira de Vasconcelos and Cassel, 2015). Thus, the effect of AIT-L inactivation or disconnection of AIT-L $\rightarrow$ DMS projections on Meth seeking might be an indirect consequence of decreased awareness of the Meth-associated cues and contexts during the relapse tests or inhibition of cue-induced and contextinduced arousal that promotes drug seeking. Second, the AIT-L has also been implicated in working-memory processes (Porter et al., 2001; Shirvalkar et al., 2006; Mair and Hembrook, 2008; Mair et al., 2011). Thus, the effect of AIT-L inactivation or disconnection of AIT-L $\rightarrow$ DMS projections on Meth seeking might be due to working-memory or memory-retrieval deficits. We think that this possibility is unlikely because, if the inactivation or disconnection manipulations strongly affected working memory or memory retrieval, these manipulations would have also decreased operant food-reinforced responding. Third, we speculate that the effect of AIT-L inactivation or disconnection of AIT-L $\rightarrow$ DMS projections on Meth seeking reflects a more general role of this brain area and its striatal projections in reward seeking for both drugs and nondrug rewards. Tentative support for this idea is the recent demonstration that optogenetic stimulation of the AIT $\rightarrow$ dorsal striatum projection in mice supports operant lever pressing (optical intracranial selfstimulation) and D1R-mediated real-time place preference (Cover et al., 2017). Additionally, Lin et al. (2015) demonstrated that deep brain stimulation of the AIT-L accelerates the acquisition of lever pressing for water in rats.

Our data from the anatomical disconnection procedure also support the hypothesis that glutamate-dopamine interaction in the DMS contributes to incubated Meth craving. These data support the notion that striatal function and striatal-dependent learned behaviors depend on an interaction between dopamine and glutamate transmission (O'Donnell, 2003; Sesack et al., 2003; Lovinger, 2010; Shiflett and Balleine, 2011). Our data are also in agreement with our studies showing that glutamate-dopamine interaction in the ventral striatum is critical for context-induced reinstatement of heroin seeking (Bossert et al., 2012, 2016). What is unknown is how glutamatergic projections from the AIT-L interact with D1R-mediated signaling in the DMS to promote Meth seeking. This question is beyond the scope of our paper, but recent findings from Mathur and colleagues might be relevant. They found that optogenetic stimulation of AIT $\rightarrow$ dorsal striatum glutamatergic projections triggers dopamine release in the dorsal striatum via activation of striatal cholinergic interneurons (Cover et al., 2017). A question for future research is whether this mechanism also plays a role in incubation of Meth craving.

\section{Concluding remarks}

We combined reversible inactivation and an asymmetrical disconnection procedure with retrograding tracer and Fos immunohistochemistry to demonstrate that activation of AIT-L $\rightarrow$ DMS glutamatergic projections plays a critical role in incubation of Meth craving via an interaction with local postsynaptic D1Rs. Within the context of the previous literature, our 
DMS findings extend previous reports by us and others on the important role of this brain region in drug-taking behavior (Wang et al., 2010; Li et al., 2015b; Logrip et al., 2015; Ron and Barak, 2016; Even-Chen et al., 2017). Additionally, our AIT-L findings extend previous reports on the important role of the nearby paraventricular nucleus of the thalamus and its projections to ventral striatum in drug taking (Neumann et al., 2016) and drug seeking (Hamlin et al., 2009; James and Dayas, 2013; Matzeu et al., 2014; Khoo et al., 2017). Last, as there is evidence for both similarities and differences in the brain mechanisms of relapse to opioid versus psychostimulant drugs (Badiani et al., 2011; Bossert et al., 2013), a question for future research is whether the AIT and AIT-L $\rightarrow$ DMS glutamatergic projections play a general role in incubation of drug craving across drug classes.

\section{References}

Adhikary S, Caprioli D, Venniro M, Kallenberger P, Shaham Y, Bossert JM (2017) Incubation of extinction responding and cue-induced reinstatement, but not context- or drug priming-induced reinstatement, after withdrawal from methamphetamine. Addict Biol 22:977-990. CrossRef Medline

Badiani A, Belin D, Epstein D, Calu D, Shaham Y (2011) Opiate versus psychostimulant addiction: the differences do matter. Nat Rev Neurosci 12:685-700. CrossRef Medline

Belin D, Everitt BJ (2008) Cocaine seeking habits depend upon dopaminedependent serial connectivity linking the ventral with the dorsal striatum. Neuron 57:432-441. CrossRef Medline

Bossert JM, Wihbey KA, Pickens CL, Nair SG, Shaham Y (2009) Role of dopamine $\mathrm{D}(1)$-family receptors in dorsolateral striatum in contextinduced reinstatement of heroin seeking in rats. Psychopharmacology 206:51-60. CrossRef Medline

Bossert JM, Stern AL, Theberge FR, Marchant NJ, Wang HL, Morales M, Shaham Y (2012) Role of projections from ventral medial prefrontal cortex to nucleus accumbens shell in context-induced reinstatement of heroin seeking. J Neurosci 32:4982-4991. CrossRef Medline

Bossert JM, Marchant NJ, Calu DJ, Shaham Y (2013) The reinstatement model of drug relapse: recent neurobiological findings, emerging research topics, and translational research. Psychopharmacology 229:453-476. CrossRef Medline

Bossert JM, Adhikary S, St Laurent R, Marchant NJ, Wang HL, Morales M, Shaham Y (2016) Role of projections from ventral subiculum to nucleus accumbens shell in context-induced reinstatement of heroin seeking in rats. Psychopharmacology 233:1991-2004. CrossRef Medline

Caprioli D, Venniro M, Zeric T, Li X, Adhikary S, Madangopal R, Marchant NJ, Lucantonio F, Schoenbaum G, Bossert JM, Shaham Y (2015) Effect of the novel positive allosteric modulator of metabotropic glutamate receptor 2 AZD8529 on incubation of methamphetamine craving after prolonged voluntary abstinence in a rat model. Biol Psychiatry 78:463-473. CrossRef Medline

Caprioli D, Venniro M, Zhang M, Bossert JM, Warren BL, Hope BT, Shaham $Y$ (2017) Role of dorsomedial striatum neuronal ensembles in incubation of methamphetamine craving after voluntary abstinence. J Neurosci 37:1014-1027. CrossRef Medline

Cover KK, Gyawali U, Marquardt AE, Mu C, Patton MH, White MG, Roberts BM, Mathur BN (2017) Rostral thalamic intralaminar nuclei modulation of striatal microcircuitry and action. Soc Neurosci Abstr 690.07.

Crombag HS, Bossert JM, Koya E, Shaham Y (2008) Review. Contextinduced relapse to drug seeking: a review. Philos Trans R Soc Lond B Biol Sci 363:3233-3243. CrossRef Medline

Cruz FC, Koya E, Guez-Barber DH, Bossert JM, Lupica CR, Shaham Y, Hope BT (2013) New technologies for examining the role of neuronal ensembles in drug addiction and fear. Nat Rev Neurosci 14:743-754. CrossRef Medline

Elkashef A, Vocci F, Hanson G, White J, Wickes W, Tiihonen J (2008) Pharmacotherapy of methamphetamine addiction: an update. Subst Abus 29: 31-49. CrossRef Medline

Even-Chen O, Sadot-Sogrin Y, Shaham O, Barak S (2017) Fibroblast growth factor 2 in the dorsomedial striatum is a novel positive regulator of alcohol consumption. J Neurosci 37:8742-8754. CrossRef Medline
Floresco SB, Seamans JK, Phillips AG (1997) Selective roles for hippocampal, prefrontal cortical, and ventral striatal circuits in radial-arm maze tasks with or without a delay. J Neurosci 17:1880-1890. Medline

Fremeau RT Jr, Troyer MD, Pahner I, Nygaard GO, Tran CH, Reimer RJ, Bellocchio EE, Fortin D, Storm-Mathisen J, Edwards RH (2001) The expression of vesicular glutamate transporters defines two classes of excitatory synapse. Neuron 31:247-260. CrossRef Medline

Fremeau RT Jr, Voglmaier S, Seal RP, Edwards RH (2004) VGLUTs define subsets of excitatory neurons and suggest novel roles for glutamate. Trends Neurosci 27:98-103. CrossRef Medline

Fuchs RA, Branham RK, See RE (2006) Different neural substrates mediate cocaine seeking after abstinence versus extinction training: a critical role for the dorsolateral caudate-putamen. J Neurosci 26:3584-3588. CrossRef Medline

Fuchs RA, Eaddy JL, Su ZI, Bell GH (2007) Interactions of the basolateral amygdala with the dorsal hippocampus and dorsomedial prefrontal cortex regulate drug context-induced reinstatement of cocaine-seeking in rats. Eur J Neurosci 26:487-498. CrossRef Medline

Gaffan D, Murray EA, Fabre-Thorpe M (1993) Interaction of the amygdala with the frontal lobe in reward memory. Eur J Neurosci 5:968-975. CrossRef Medline

Groenewegen HJ, Berendse HW (1994) The specificity of the 'nonspecific' midline and intralaminar thalamic nuclei. Trends Neurosci 17:52-57. CrossRef Medline

Guo Q, Wang D, He X, Feng Q, Lin R, Xu F, Fu L, Luo M (2015) Wholebrain mapping of inputs to projection neurons and cholinergic interneurons in the dorsal striatum. PLoS One 10:e0123381. CrossRef Medline

Hamlin AS, Clemens KJ, Choi EA, McNally GP (2009) Paraventricular thalamus mediates context-induced reinstatement (renewal) of extinguished reward seeking. Eur J Neurosci 29:802-812. CrossRef Medline

Hunnicutt BJ, Jongbloets BC, Birdsong WT, Gertz KJ, Zhong H, Mao T (2016) A comprehensive excitatory input map of the striatum reveals novel functional organization. Elife 5:e19103. CrossRef Medline

James MH, Dayas CV (2013) What about me.? The PVT: a role for the paraventricular thalamus (PVT) in drug-seeking behavior. Front Behav Neurosci 7:18. CrossRef Medline

Jenni NL, Larkin JD, Floresco SB (2017) Prefrontal dopamine D1 and D2 receptors regulate dissociable aspects of decision making via distinct ventral striatal and amygdalar circuits. J Neurosci 37:6200-6213. CrossRef Medline

Khoo SY, Gibson GD, Prasad AA, McNally GP (2017) How contexts promote and prevent relapse to drug seeking. Genes Brain Behav 16:185-204. CrossRef Medline

Lasseter HC, Wells AM, Xie X, Fuchs RA (2011) Interaction of the basolateral amygdala and orbitofrontal cortex is critical for drug context-induced reinstatement of cocaine-seeking behavior in rats. Neuropsychopharmacology 36:711-720. CrossRef Medline

Li X, Zeric T, Kambhampati S, Bossert JM, Shaham Y (2015a) The central amygdala nucleus is critical for incubation of methamphetamine craving. Neuropsychopharmacology 40:1297-1306. CrossRef Medline

Li X, Rubio FJ, Zeric T, Bossert JM, Kambhampati S, Cates HM, Kennedy PJ Liu QR, Cimbro R, Hope BT, Nestler EJ, Shaham Y (2015b) Incubation of methamphetamine craving is associated with selective increases in expression of $B d n f$ and $T r k b$, glutamate receptors, and epigenetic enzymes in cue-activated Fos-expressing dorsal striatal neurons. J Neurosci 35: 8232-8244. CrossRef Medline

Lin HC, Pan HC, Lin SH, Lo YC, Shen ET, Liao LD, Liao PH, Chien YW, Liao KD, Jaw FS, Chu KW, Lai HY, Chen YY (2015) Central thalamic deepbrain stimulation alters striatal-thalamic connectivity in cognitive neural behavior. Front Neural Circuits 9:87. CrossRef Medline

Logrip ML, Barak S, Warnault V, Ron D (2015) Corticostriatal BDNF and alcohol addiction. Brain Res 1628:60-67. CrossRef Medline

Lovinger DM (2010) Neurotransmitter roles in synaptic modulation, plasticity and learning in the dorsal striatum. Neuropharmacology 58:951961. CrossRef Medline

Lu L, Grimm JW, Hope BT, Shaham Y (2004) Incubation of cocaine craving after withdrawal: a review of preclinical data. Neuropharmacology 47 [Suppl 1]:214-226. CrossRef Medline

Lu L, Uejima JL, Gray SM, Bossert JM, Shaham Y (2007) Systemic and central amygdala injections of the mGluR(2/3) agonist LY379268 attenuate the expression of incubation of cocaine craving. Biol Psychiatry 61:591598. CrossRef Medline 
Mair RG, Hembrook JR (2008) Memory enhancement with event-related stimulation of the rostral intralaminar thalamic nuclei. J Neurosci 28: 14293-14300. CrossRef Medline

Mair RG, Onos KD, Hembrook JR (2011) Cognitive activation by central thalamic stimulation: the Yerkes-Dodson law revisited. Dose Response 9:313-331. CrossRef Medline

Marchant NJ, Hamlin AS, McNally GP (2009) Lateral hypothalamus is required for context-induced reinstatement of extinguished reward seeking. J Neurosci 29:1331-1342. CrossRef Medline

Marchant NJ, Rabei R, Kaganovsky K, Caprioli D, Bossert JM, Bonci A, Shaham Y (2014) A critical role of lateral hypothalamus in context-induced relapse to alcohol seeking after punishment-imposed abstinence. J Neurosci 34:7447-7457. CrossRef Medline

Marchant NJ, Campbell EJ, Whitaker LR, Harvey BK, Kaganovsky K, Adhikary S, Hope BT, Heins RC, Prisinzano TE, Vardy E, Bonci A, Bossert JM, Shaham Y (2016) Role of ventral subiculum in context-induced relapse to alcohol seeking after punishment-imposed abstinence. J Neurosci 36:3281-3294. CrossRef Medline

Matzeu A, Zamora-Martinez ER, Martin-Fardon R (2014) The paraventricular nucleus of the thalamus is recruited by both natural rewards and drugs of abuse: recent evidence of a pivotal role for orexin/hypocretin signaling in this thalamic nucleus in drug-seeking behavior. Front Behav Neurosci 8:117. CrossRef Medline

McFarland K, Kalivas PW (2001) The circuitry mediating cocaine-induced reinstatement of drug-seeking behavior. J Neurosci 21:8655-8663. Medline

Neumann PA, Wang Y, Yan Y, Wang Y, Ishikawa M, Cui R, Huang YH, Sesack SR, Schlüter OM, Dong Y (2016) Cocaine-induced synaptic alterations in thalamus to nucleus accumbens projection. Neuropsychopharmacology 41:2399-2410. CrossRef Medline

Newman LA, Mair RG (2007) Cholinergic modulation of visuospatial responding in central thalamus. Eur J Neurosci 26:3543-3552. CrossRef Medline

O’Donnell P (2003) Dopamine gating of forebrain neural ensembles. Eur J Neurosci 17:429-435. CrossRef Medline

Paxinos G, Watson C (2005) The rat brain in stereotaxic coordinates, fifth edition. Amsterdam: Elsevier Academic.

Pereira de Vasconcelos A, Cassel JC (2015) The nonspecific thalamus: a place in a wedding bed for making memories last? Neurosci Biobehav Rev 54:175-196. CrossRef Medline

Peters J, Vallone J, Laurendi K, Kalivas PW (2008) Opposing roles for the ventral prefrontal cortex and the basolateral amygdala on the spontaneous recovery of cocaine-seeking in rats. Psychopharmacology 197:319326. CrossRef Medline

Pickens CL, Airavaara M, Theberge F, Fanous S, Hope BT, Shaham Y (2011) Neurobiology of incubation of cocaine craving. Trends Neurosci 34:411420. CrossRef Medline

Porter MC, Koch J, Mair RG (2001) Effects of reversible inactivation of thalamo-striatal circuitry on delayed matching trained with retractable levers. Behav Brain Res 119:61-69. CrossRef Medline

Ron D, Barak S (2016) Molecular mechanisms underlying alcohol-drinking behaviours. Nat Rev Neurosci 17:576-591. CrossRef Medline

Rubio FJ, Liu QR, Li X, Cruz FC, Leão RM, Warren BL, Kambhampati S, Babin KR, McPherson KB, Cimbro R, Bossert JM, Shaham Y, Hope BT (2015) Context-induced reinstatement of methamphetamine seeking is associated with unique molecular alterations in Fos-expressing dorsolateral striatum neurons. J Neurosci 35:5625-5639. CrossRef Medline

Scheyer AF, Loweth JA, Christian DT, Uejima J, Rabei R, Le T, Dolubizno H, Stefanik MT, Murray CH, Sakas C, Wolf ME (2016) AMPA receptor plasticity in accumbens core contributes to incubation of methamphetamine craving. Biol Psychiatry 80:661-670. CrossRef Medline

Schiff ND (2008) Central thalamic contributions to arousal regulation and neurological disorders of consciousness. Ann N Y Acad Sci 1129:105-118. CrossRef Medline

Sesack SR, Carr DB, Omelchenko N, Pinto A (2003) Anatomical substrates for glutamate-dopamine interactions: evidence for specificity of connections and extrasynaptic actions. Ann N Y Acad Sci 1003:36-52. CrossRef Medline

Setlow B, Holland PC, Gallagher M (2002) Disconnection of the basolateral amygdala complex and nucleus accumbens impairs appetitive Pavlovian second-order conditioned responses. Behav Neurosci 116:267-275. CrossRef Medline

Shalev U, Grimm JW, Shaham Y (2002) Neurobiology of relapse to heroin and cocaine seeking: a review. Pharmacol Rev 54:1-42. CrossRef Medline

Shepard JD, Bossert JM, Liu SY, Shaham Y (2004) The anxiogenic drug yohimbine reinstates methamphetamine seeking in a rat model of drug relapse. Biol Psychiatry 55:1082-1089. CrossRef Medline

Shiflett MW, Balleine BW (2011) Molecular substrates of action control in cortico-striatal circuits. Prog Neurobiol 95:1-13. CrossRef Medline

Shirvalkar P, Seth M, Schiff ND, Herrera DG (2006) Cognitive enhancement with central thalamic electrical stimulation. Proc Natl Acad Sci U S A 103:17007-17012. CrossRef Medline

Tervo DG, Hwang BY, Viswanathan S, Gaj T, Lavzin M, Ritola KD, Lindo S, Michael S, Kuleshova E, Ojala D, Huang CC, Gerfen CR, Schiller J, Dudman JT, Hantman AW, Looger LL, Schaffer DV, Karpova AY (2016) A designer AAV variant permits efficient retrograde access to projection neurons. Neuron 92:372-382. CrossRef Medline

Theberge FR, Li X, Kambhampati S, Pickens CL, St Laurent R, Bossert JM, Baumann MH, Hutchinson MR, Rice KC, Watkins LR, Shaham Y (2013) Effect of chronic delivery of the toll-like receptor 4 antagonist $(+)$ naltrexone on incubation of heroin craving. Biol Psychiatry 73:729-737. CrossRef Medline

Valjent E, Corvol JC, Pages C, Besson MJ, Maldonado R, Caboche J (2000) Involvement of the extracellular signal-regulated kinase cascade for cocaine-rewarding properties. J Neurosci 20:8701-8709. Medline

Van der Werf YD, Witter MP, Groenewegen HJ (2002) The intralaminar and midline nuclei of the thalamus. Anatomical and functional evidence for participation in processes of arousal and awareness. Brain Res Brain Res Rev 39:107-140. CrossRef Medline

Vanderschuren LJ, Di Ciano P, Everitt BJ (2005) Involvement of the dorsal striatum in cue-controlled cocaine seeking. J Neurosci 25:8665-8870. CrossRef Medline

Venniro M, Zhang M, Shaham Y, Caprioli D (2017) Incubation of methamphetamine but not heroin craving after voluntary abstinence in male and female rats. Neuropsychopharmacology 42:1126-1135. CrossRef Medline

Voorn P, Vanderschuren LJ, Groenewegen HJ, Robbins TW, Pennartz CM (2004) Putting a spin on the dorsal-ventral divide of the striatum. Trends Neurosci 27:468-474. CrossRef Medline

Wang G, Shi J, Chen N, Xu L, Li J, Li P, Sun Y, Lu L (2013) Effects of length of abstinence on decision-making and craving in methamphetamine abusers. PLoS One 8:e68791. CrossRef Medline

Wang J, Lanfranco MF, Gibb SL, Yowell QV, Carnicella S, Ron D (2010) Long-lasting adaptations of the NR2B-containing NMDA receptors in the dorsomedial striatum play a crucial role in alcohol consumption and relapse. J Neurosci 30:10187-10198. CrossRef Medline

Wolf ME (2016) Synaptic mechanisms underlying persistent cocaine craving. Nat Rev Neurosci 17:351-365. CrossRef Medline 